\title{
Development of Membraneless Sodium Perborate Fuel Cell for Media Flexible Power Generation
}

\author{
K. Ponmani, ${ }^{1}$ S. Durga, ${ }^{1}$ A. Arun, ${ }^{1}$ S. Kiruthika, ${ }^{2}$ and B. Muthukumaran ${ }^{1}$ \\ ${ }^{1}$ Department of Chemistry, Presidency College, Chennai 600 005, India \\ ${ }^{2}$ Department of Chemical Engineering, SRM University, Chennai 603 203, India
}

Correspondence should be addressed to B. Muthukumaran; dr.muthukumaran@yahoo.com

Received 19 November 2013; Revised 8 January 2014; Accepted 9 January 2014; Published 27 March 2014

Academic Editor: Mohamed Mohamedi

Copyright ( $\odot 2014$ K. Ponmani et al. This is an open access article distributed under the Creative Commons Attribution License, which permits unrestricted use, distribution, and reproduction in any medium, provided the original work is properly cited.

This paper reports the media flexibility of membraneless sodium perborate fuel cell (MLSPBFC) using acid/alkaline bipolar electrolyte in which the anode is in acidic media while the cathode is in alkaline media, or vice versa. Investigation of the cell operation is conducted by using formic acid as a fuel and sodium perborate as an oxidant for the first time under "acid-alkaline media" configurations. The MLSPBFC architecture enables interchangeable operation with different media combinations. The experimental results indicate that operating under "acid-alkaline media" conditions significantly improves the fuel cell performance compared with all-acidic and all-alkaline conditions. The effects of flow rates and the concentrations of various species at both the anode and cathode on the cell performance are also investigated. It has been demonstrated that the laminar flow based microfluidic membraneless fuel cell can reach a maximum power density of $28.2 \mathrm{~mW} \mathrm{~cm}^{-2}$ with a fuel mixture flow rate of $0.3 \mathrm{~mL} \mathrm{~min}^{-1}$ at room temperature.

\section{Introduction}

The portable multifunctional electronic devices with high speed operations necessitate better energy storage and supply options that deliver increased power and energy density. Current battery technologies appear to be approaching a performance plateau, insufficient to meet the needs of future devices. Portable fuel cells, while being a battery alternative that shows good potential to meet future needs, have yet to resolve a number of technical challenges. As a result, several microfabrication techniques are developed to increase the power density because miniaturization of fuel cells stacks and components increases the electrochemically active surface area to volume ratio, which is an important consideration to improve performance.

A novel microfabrication method-fabrication inside capillaries using multistream laminar flow-provided the idea for a new type of fuel cell, which eliminates several of the technical issues related to the use of proton exchange membrane fuel cells (PEMFCs), such as fuel crossover [1], membrane degradation, long startup time, ohmic losses, size, fabrication, and water management limited durability of catalysts [2]. A membrane, as used in membrane-electrode assemblies (MEAs), brings about a resistance to the transport of ions through the electrolytes. Furthermore, MEAs are expensive components at present. Therefore, the cell structure without the membrane has two merits, decrease of electrical resistivity in the cell and inexpensive material cost.

A membraneless fuel cell is a device that does not contain membrane, and it converts chemical energy from a fuel and an oxidant into electric energy, by means of oxidoreduction reactions. It eliminates the above problems of PEMFCs associated with membranes. Membraneless micro fuel cells use liquid reactants (fuel and oxidant) that flow side by side in a laminar fashion in a single channel without a membrane. Anode and cathode electrodes are positioned on the opposing channel walls and the mixing of fuel and oxidant in the channel occurs only by diffusion. Apart from the conventional fuel cells (PEMFCs), the membraneless micro fuel cell does not need anode or cathode humidification and maintains the water level in the cell because flowing stream can automatically remove water out of the cell. As a result, the water management is not needed [3]. Furthermore, the structures of membraneless micro fuel cells are very simple 
TABLE 1: Theoretical open-circuit potential and maximum efficiency of various fuels.

\begin{tabular}{lcccccc}
\hline Fuel & Reaction & $n(\mathrm{e})$ & $-\Delta H^{\circ}(\mathrm{kJ} / \mathrm{mol})$ & $-\Delta G^{\circ}(\mathrm{kJ} / \mathrm{mol})$ & $E_{\text {rev }}^{\circ}(\mathrm{V})$ & Maximum efficiency $(\%)$ \\
\hline Ethanol & $\mathrm{CH}_{3} \mathrm{CH}_{2} \mathrm{OH}+3 \mathrm{O}_{2} \rightarrow 2 \mathrm{CO}_{2}+3 \mathrm{H}_{2} \mathrm{O}$ & 12 & 277.7 & 174.9 & 1.15 & 62.98 \\
Hydrogen & $\mathrm{H}_{2}+1 / 2 \mathrm{O}_{2} \rightarrow \mathrm{H}_{2} \mathrm{O}$ & 2 & 286 & 237.3 & 1.23 & 82.97 \\
$\mathrm{~V}^{2+}$ & $\mathrm{V}^{2+}+\mathrm{VO}^{2+}+2 \mathrm{H}^{+} \rightarrow \mathrm{V}^{3+}+\mathrm{VO}^{2+}+\mathrm{H}_{2} \mathrm{O}$ & 1 & 431.8 & 404.2 & 1.19 & 93.61 \\
Methanol & $\mathrm{CH}_{3} \mathrm{OH}+1 / 2 \mathrm{O}_{2} \rightarrow \mathrm{CO}_{2}+2 \mathrm{H}_{2} \mathrm{O}$ & 6 & 726.6 & 702.5 & 1.21 & 96.68 \\
Formic acid & $\mathrm{HCOOH}+1 / 2 \mathrm{O}_{2} \rightarrow \mathrm{CO}_{2}+2 \mathrm{H}_{2} \mathrm{O}$ & 2 & 270.3 & 285.5 & 1.48 & 105.6 \\
\hline
\end{tabular}

and easy to miniaturize [4], so that light and stackable fuel cells can be fabricated with simple microelectromechanical systems (MEMS) [5, 6]. The flexibility and the performance implications of operating membraneless sodium perborate fuel cell (MLSPBFC) under "acid-alkaline media," that is, one electrode is acidic and the other one is alkaline condition, will be the focus of this study.

Recent catalysis and fuel cell research has indicated that formic acid may be a good alternative to the common fuels of hydrogen and methanol [7, 8]. Even though formic acid has a lower energy density than methanol, 7.49 and $17.5 \mathrm{~J} / \mathrm{mL}$, respectively, the possibility for a significant increase in performance with the correct catalyst exists [9]. Compared to hydrogen and methanol, formic acid has a higher overall theoretical open circuit potential and maximum efficiency as indicated in Table 1. In sum, formic acid seems to be a promising fuel for fuel cells and thus will be explored as the fuel with the membraneless fuel cell in this paper.

However, since the previous researchers used oxygen solution as the oxidant, the performance of these micro fuel cells was found to be restricted severely by the low transport efficiency of oxygen in the cathode stream.

In this communication, for the first time we introduce sodium perborate $\left(\mathrm{NaBO}_{3} \cdot 4 \mathrm{H}_{2} \mathrm{O}\right)$ as an oxidant under "acid-alkaline media" to demonstrate the performance of a membraneless sodium perborate fuel cell (MLSPBFC). Sodium perborate is a true peroxo salt and is a convenient source of hydrogen peroxide $[10,11]$ :

$$
\left[\mathrm{B}(\mathrm{OH})_{3}\left(\mathrm{O}_{2} \mathrm{H}\right)\right]^{-}+\mathrm{H}_{2} \mathrm{O} \rightleftharpoons\left[\mathrm{B}(\mathrm{OH})_{4}\right]^{-}+\mathrm{H}_{2} \mathrm{O}_{2}
$$

The sodium perborate fuel cell (MLSPBFC) is unique from previous fuel cells using $\mathrm{H}_{2} \mathrm{O}_{2}$; as mentioned in our earlier study sodium perborate can be used not only as an oxidant but also as a reductant $[12,13]$.

The MLSPBFC has some advantages; for example, sodium perborate is a cheap, nontoxic, and large scale industrial chemical which is used primarily in detergents and as a mild oxidant [14]. The cell being more environmentally friendly than the other fuel cells and the sodium perborate can be handled more simply than hydrogen, as it is a wellknown fact that sodium perborate solution is a widespread safe disinfectant. On the performance side, the MLSPBFC generates electric power comparable to a typical air-breathing DMFC when operated in a microchemical channel at room temperature. In addition, the MLSPBFC requires no membrane electrode assemblies. Thus, the cost for the materials is low and the structure of the cell is simple.
TABLE 2: Summary of the theoretical energy densities for different fuels.

\begin{tabular}{lcc}
\hline Fuel & $\begin{array}{c}\text { Gravimetric energy } \\
\text { density }\left(\mathrm{Wh} \mathrm{kg}^{-1}\right)\end{array}$ & $\begin{array}{c}\text { Volumetric energy } \\
\text { density }\left(\mathrm{Wh} \mathrm{L}^{-1}\right)\end{array}$ \\
\hline Formic acid & 2086 & 1710 \\
Sodium borohydride & 2925 & 2840 \\
Methanol & 4690 & 6400 \\
Ethanol & 6100 & 7850 \\
\hline
\end{tabular}

Since formic acid fuel cells are capable of delivering higher energy densities than the most competitive rechargeable batteries [15] and can easily be obtained from fossil fuels, such as natural gas or coal, as well as from existence sources through fermentation of agricultural products and from biomasses, we use formic acid as a fuel to study the performance of MLSPBFC in this work. This is an important metric in the development of converged electronic devices as the operating time is becoming limited by conventional battery technology. Table 2 provides relevant data about the alternative fuels and their theoretical energy densities. These fuels exhibit higher volumetric and gravimetric energy densities than batteries. Many works are under progress on the development of microfluidic direct formic acid fuel cells [16-19].

Moreover, in recent years, the effect of operating laminar flow based fuel cells in all-acidic, all-alkaline, and acidic/alkaline medium is highly focused [20, 21]. Since certain hydrocarbons such as formic acid and methanol can easily be stored in liquid form under ambient conditions are known to give safer high energy densities. As for the acid/alkaline bipolar electrolyte, Ayato et al. used a polymerelectrolyte membrane consisting of acid and alkaline ionexchange layers for a HFC [22]. The function of their bipolar membrane was mainly to keep the power stable by modifying water management. On the other hand, we use the bipolar electrolyte to force reactions (3) and (5) to proceed. Thus, the use of perborate in the acid/alkaline bipolar electrolyte is characteristic of the MLSPBFC.

In this study a new branch of simplified architectures that is unique from those that have been reported in the literature has been developed by eliminating and integrating the key components of a conventional MEA. With these advantages, membraneless sodium perborate fuel cells (MLSPBFC) can be used as an alternative for portable power applications. 


\section{Experimental}

2.1. Materials and Reagents. The materials and chemicals used during the tests are listed as follows: $\mathrm{HCOOH}$ (98\%, Merck), $\quad \mathrm{NaBO}_{3} \cdot 4 \mathrm{H}_{2} \mathrm{O}$ (99\%, Riedel), $\mathrm{NaOH}$ (98\%, Merck) and $\mathrm{H}_{2} \mathrm{SO}_{4}$ (98\%, Merck), PDMS poly(dimethylsiloxane) (99.9\%, Chemsworth), and PMMA poly(methylmethacrylate) (92\%, G. Khanna \& Co.), graphite plates (Kriti Graphite), and silicon tubes (Shree Gaurav Rubber Products). All experiments were conducted at room temperature using formic acid in deionised water as a fuel and sodium perborate in deionised water as an oxidant and $0.5 \mathrm{M} \mathrm{NaOH}$ and $0.5 \mathrm{M} \mathrm{H}_{2} \mathrm{SO}_{4}$ in deionised water as electrolytes.

2.2. Catalyst Deposition. For all the experiments of MLSPBFC, unsupported platinum black nanoparticles are applied to the sides of the graphite plates to act as cathode and anode that line the microfluidic channel. The catalyst suspensions for both anode and cathode were prepared by mixing at a concentration of $6.0 \mathrm{mg} \mathrm{mL}^{-1} \mathrm{Pt}$ black nanoparticles (Alpha Aesar) in a $10 \mathrm{wt} \%$ Nafion solution (Nafion stock solution: Dupont, 5\% $(w / w)$ solution). This mixture was sonicated and applied to the side faces of the graphite plates at a loading of $2 \mathrm{mg} \mathrm{cm}^{-2}$. Then solvent was evaporated by the use of a heat lamp for uniform loading.

2.3. Design of Membraneless Sodium Perborate Fuel Cells (MLSPBFC). In the MLSPBFC configuration, an E-shaped laminar flow channel with catalyst-coated graphite plates of $1 \mathrm{~mm}$ thickness is used. After subsequent deposition of catalyst to the cathode and anode, the E-shaped microfluidic channel structure is molded with PDMS poly(dimethylsiloxane), typically $1-10 \mathrm{~mm}$ in thickness, and finally sealed with a solid substrate such as $2 \mathrm{~mm}$ thick pieces of PMMA poly(methylmethacrylate) to provide rigidity and supportive strength to the layered system. Silicon tubing is placed to guide the fuel and oxidant into the E-shaped channel systems at the top and to guide the waste stream out at the bottom of the channel (Figure 1).

2.4. Test of the Fuel Cell. The solutions of fuel and oxidant were pumped through the device using a syringe pump (Schiller India). The flow rate of each of the streams was $0.3 \mathrm{~mL} \mathrm{~min}^{-1}$ (total flow rate of $0.6 \mathrm{~mL} \mathrm{~min}^{-1}$ ). Also, the cell was allowed to run for an hour for the flow to reach a steady state. When injected through the inlets, fuel and oxidant solutions will merge at the E-junction and continue to flow laminarly in parallel over the anode and cathode where fuel and oxidant are allowed to be oxidized and reduced, respectively. Cell measurements were conducted using a CS310 computer controlled potentiostat (Zhengzhou Triangle Instrument Co., Ltd.) with the associated Thales $\mathrm{Z}$ software package. For each analysed factor, the performance of the fuel cell was evaluated by recording the cell polarisation and obtaining the corresponding power density curves. Consequently, the microfluidic cell keeps these fluids stable without a separation membrane.

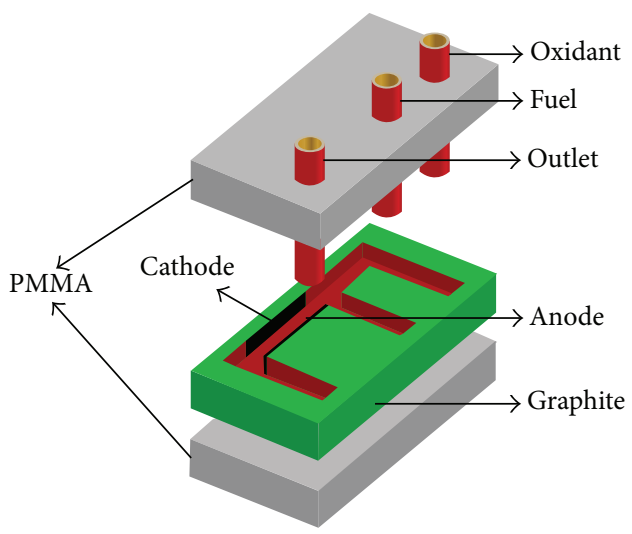

FIGURE 1: Schematic of the E-shaped membraneless laminar flow based fuel cell with graphite plates molded with PDMS poly(dimethylsiloxane) and sealed with PMMA poly(methylmethacrylate).

2.5. Acid-Alkaline Media Flexibility of MLSPBFC. This membraneless microfabrication method eliminates several of the technical issues related to the use of polymer electrolyte membrane fuel cells (PEMs) [23, 24]. In addition, lack of a membrane also allows for operation of MLSPBFC in more than one medium. Moreover, the chemical composition of the cathode and anode streams can be designed individually to optimize individual electrode kinetics as well as overall cell potential. Furthermore, the MLSPBFC has the flexibility to run in all-acidic, all-alkaline media or in an "acid-alkaline media" mode in which the anode is exposed to acidic media while the cathode is exposed to alkaline media, or vice versa. The performance of MLSPBFC in acid-alkaline media configuration, using an alkaline anode and an acidic cathode results in a higher overall cell potential than those obtained from all-acidic and all-alkaline fuel cell experiments.

\section{Results and Discussion}

Two different approaches have been pursued: the first step consisted in the flexibility and the performance implications of operating membraneless sodium perborate fuel cell (MLSPBFC) under "acid-alkaline media" configuration; the second step was intended to further improve the cell performance by characterising the main cell by changing several operational parameters, namely, the fuels' compositions, oxidants' compositions, electrolytes' compositions, distance effect and flow rate, and to observe their influence on the polarisation behaviour of the cell.

3.1. Performance of MLSPBFC in All-Acidic and All-Alkaline Media. The $\mathrm{pH}$ of the electrolyte has an effect on reaction kinetics at the individual electrodes, as well as the electrode potential at which oxidation or reduction occurs [25-29]. Equations (2) and (3) represent the half-cell reactions and standard electrode potentials of formic acid oxidation and peroxide reduction in acidic media and (5) and (6) represent the alkaline media. Equation (7) shows the overall cell 


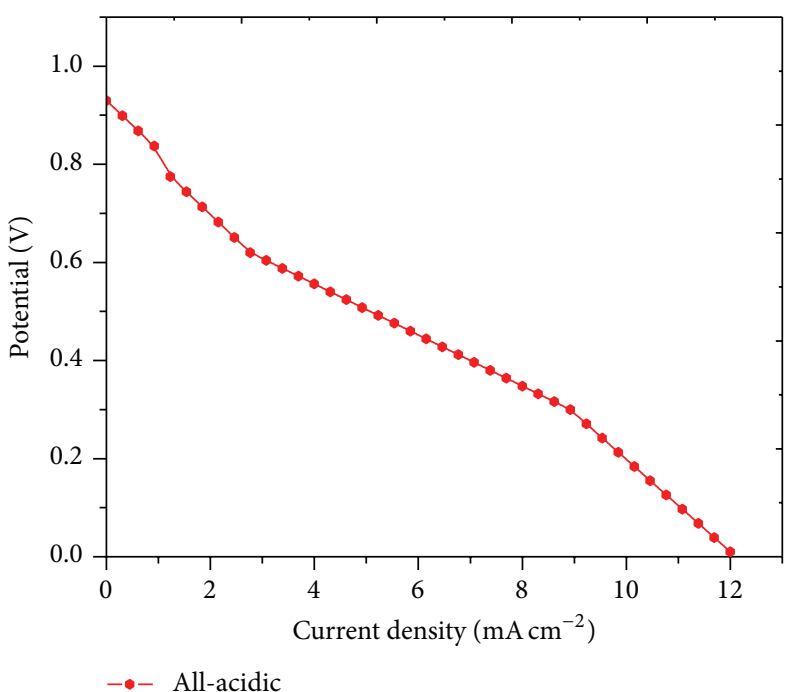

(a)

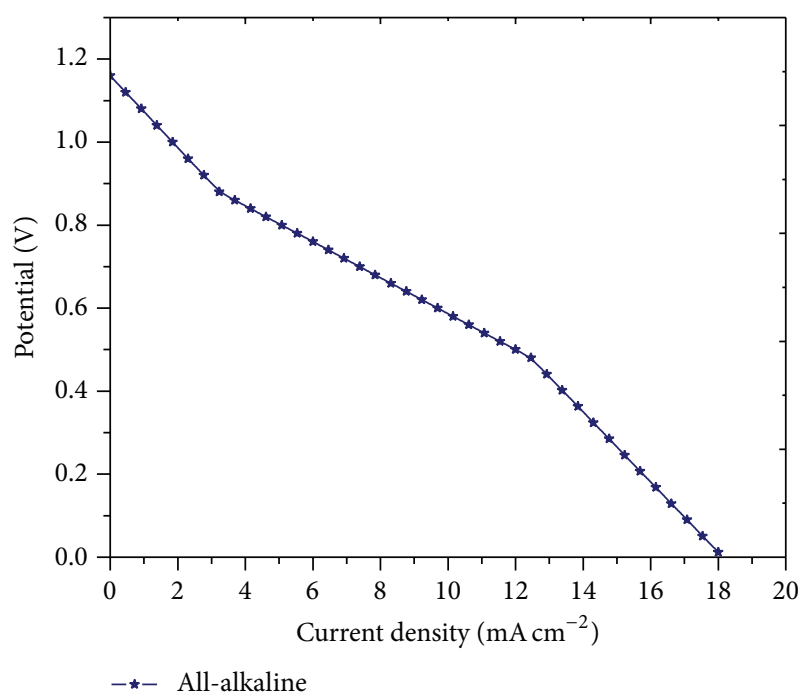

(b)

FIGURE 2: Polarisation curves for overall cell performance of MLSPBFC operating in (a) all-acidic and (b) all-alkaline media at room temperature. For both experiments the fuel stream is $2 \mathrm{M}$ formic acid $+0.5 \mathrm{M} \mathrm{NaOH}$ (a) and in $0.5 \mathrm{M} \mathrm{H}_{2} \mathrm{SO}_{4}$ (b) and the oxidant stream is $0.1 \mathrm{M}$ perborate $+0.5 \mathrm{M} \mathrm{NaOH}$ (a) and $0.5 \mathrm{M} \mathrm{H}_{2} \mathrm{SO}_{4}$ (b). Stream flow rates: $0.3 \mathrm{~mL} \mathrm{~min}^{-1}$.

reaction, in all-acid or all-alkaline media. Both the alkalinealkaline media and the acidic-acidic media have a maximum theoretical open circuit potential (OCP) of $2.156 \mathrm{~V}$ and $1.56 \mathrm{~V}$, respectively. Consider the following.

Formic acid/perborate in acidic media:

Anode:

$$
\mathrm{HCOOH} \longrightarrow \mathrm{CO}_{2}+2 \mathrm{H}^{+}+2 \mathrm{e}^{-} \quad E^{\circ}=0.22 \mathrm{~V}
$$

Cathode:

$$
3 \mathrm{H}_{2} \mathrm{O}_{2}+6 \mathrm{H}^{+}+6 \mathrm{e}^{-} \longrightarrow 6 \mathrm{H}_{2} \mathrm{O} \quad E^{\circ}=1.78 \mathrm{~V}
$$

Overall reaction, all-acidic media:

$\mathrm{HCOOH}+3 \mathrm{H}_{2} \mathrm{O}_{2}+4 \mathrm{H}^{+}+4 \mathrm{e}^{-} \longrightarrow \mathrm{CO}_{2}+6 \mathrm{H}_{2} \mathrm{O}$

$E^{\circ}=1.56 \mathrm{~V}$

Formic acid/perborate in alkaline media:

Anode:

$$
\begin{aligned}
& 2 \mathrm{HCOO}^{-}+6 \mathrm{OH}^{-} \longrightarrow 2 \mathrm{CO}_{3}{ }^{2-}+4 \mathrm{H}_{2} \mathrm{O}+4 \mathrm{e}^{-} \\
& E^{\circ}=-1.17 \mathrm{~V}
\end{aligned}
$$

Cathode:

$$
3 \mathrm{H}_{2} \mathrm{O}_{2}+6 \mathrm{e}^{-} \longrightarrow 6 \mathrm{OH}^{-} \quad E^{\circ}=0.986 \mathrm{~V}
$$

Overall reaction, all-alkaline media:

$$
\begin{aligned}
& 2 \mathrm{HCOO}^{-}+3 \mathrm{H}_{2} \mathrm{O}_{2}+2 \mathrm{e}^{-} \longrightarrow 2 \mathrm{CO}_{3}{ }^{2-}+4 \mathrm{H}_{2} \mathrm{O} \\
& E^{\circ}=2.156 \mathrm{~V}
\end{aligned}
$$

A comparison of the performance of an MLSPBFC in all-acidic and all-alkaline media is exhibited in
Figures 2(a) and 2(b), respectively. Initially at low current densities both the polarization curves are identical, and thus the performance of MLSPBFC is independent of the medium. The mass transport limitation region is around $6 \mathrm{~mA} \mathrm{~cm}^{-2}$ in the MLSPBFC running for both alkaline and acidic media. The MLSPBFC were run over several days without any drop in their performance at a wide variety of test conditions. No issues with carbonate formation were encountered in these MLSPBFC at room temperature, as any carbonate that does form is immediately removed from the system by the flowing streams.

3.2. Performance of MLSPBFC in Acid-Alkaline Media 1: Acidic Anode, Alkaline Cathode. The performance of MLSPBFC using a fuel stream of $2 \mathrm{M}$ Formic acid in $0.5 \mathrm{M}$ $\mathrm{H}_{2} \mathrm{SO}_{4}$ and an oxidant stream of $0.1 \mathrm{M}$ perborate in $0.5 \mathrm{M}$ $\mathrm{NaOH}$ was investigated. The measurements were carried out at room temperature for two configurations: acid-alkaline media 1: acidic anode, alkaline cathode and acid-alkaline media 2: alkaline anode, acidic cathode. In these acid-alkaline media configurations the neutralization reaction of $\mathrm{OH}^{-}$and $\mathrm{H}^{+}$to water occurs at the liquid-liquid interface between the fuel and oxidant stream. In the first configuration, the overall cell reaction, (10), can be obtained from (2) and (6).

Acid-alkaline media 1: acidic anode and alkaline cathode: Anode:

$$
\mathrm{HCOOH} \longrightarrow \mathrm{CO}_{2}+2 \mathrm{H}^{+}+2 \mathrm{e}^{-} \quad E^{\circ}=0.22 \mathrm{~V}
$$

Cathode:

$$
\mathrm{H}_{2} \mathrm{O}_{2}+2 \mathrm{e}^{-} \longrightarrow 2 \mathrm{OH}^{-} \quad E^{\circ}=0.986 \mathrm{~V}
$$




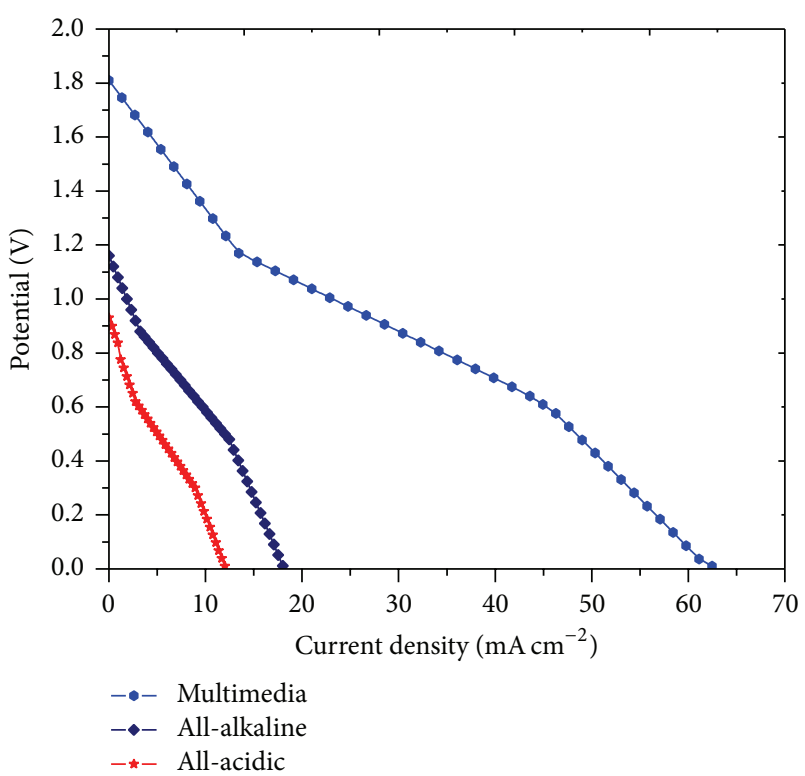

Figure 3: Polarisation curves of MLSPBFC with an alkaline anode and acidic cathode (acid-alkaline media) at room temperature. For comparison, also the polarisation curves of the MLSPBFC run in allalkaline and in all-acidic media are included. [Fuel]: $2 \mathrm{M}$ formic acid $+0.5 \mathrm{M} \mathrm{NaOH}$. [Oxidant]: $0.1 \mathrm{M}$ perborate $+0.5 \mathrm{M} \mathrm{H}_{2} \mathrm{SO}_{4}$. Stream flow rates: $0.3 \mathrm{~mL} \mathrm{~min}^{-1}$.

Overall:

$$
\begin{aligned}
& \mathrm{HCOOH}+3 \mathrm{H}_{2} \mathrm{O}_{2} \longrightarrow \mathrm{CO}_{2}+2 \mathrm{H}^{+}+2 \mathrm{OH}^{-} \\
& E^{\circ}=0.766 \mathrm{~V}
\end{aligned}
$$

In this acid-alkaline media configuration 1 , the maximum theoretical OCP is $0.766 \mathrm{~V}$. The energy liberated in the formic acid oxidation and peroxide reduction reactions is mostly consumed by the water ionization reaction. In this configuration, coexistence of the galvanic and methanol electrolytic reactions has been found to be the reason for incapability of yielding useful amounts of energy and was not studied any further.

3.3. Performance of MLSPBFC in Acid-Alkaline Media 2: Alkaline Anode, Acidic Cathode. In contrast, in acid-alkaline media configuration 2, the MLSPBFC using a fuel stream of an alkaline anode and an acidic cathode allows energy to be obtained both from the formic acid oxidation/peroxide reduction reactions and from the acid/alkali electrochemical neutralization reactions, as evident from the overall cell reaction equation (13).

Acid-alkaline media 2: alkaline anode, acidic cathode:

Anode:

$$
\begin{aligned}
& \mathrm{HCOO}^{-}+3 \mathrm{OH}^{-} \longrightarrow \mathrm{CO}_{3}{ }^{2-}+2 \mathrm{H}_{2} \mathrm{O}+2 \mathrm{e}^{-} \\
& E^{\circ}=-1.17 \mathrm{~V}
\end{aligned}
$$

Cathode:

$$
3 \mathrm{H}_{2} \mathrm{O}_{2}+6 \mathrm{H}^{+}+6 \mathrm{e}^{-} \longrightarrow 6 \mathrm{H}_{2} \mathrm{O} \quad E^{\circ}=1.78 \mathrm{~V}
$$

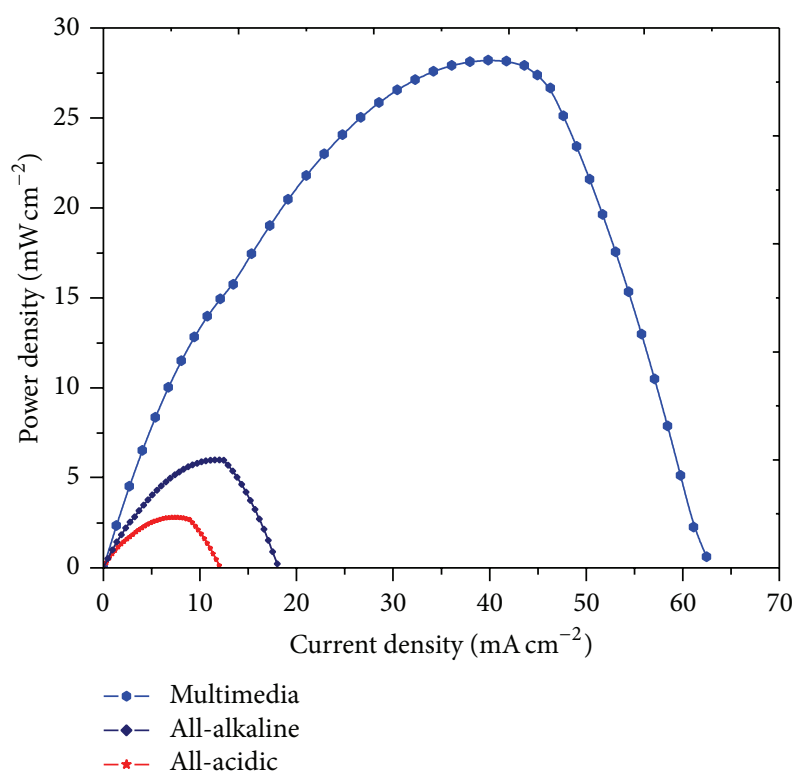

FIGURE 4: Power density curves for overall cell performance of MLSPBFC operating in alkaline $(0.5 \mathrm{M} \mathrm{NaOH})$, acidic $(0.5 \mathrm{M}$ $\mathrm{H}_{2} \mathrm{SO}_{4}$ ), and mixed-media (anode: $0.5 \mathrm{M} \mathrm{NaOH}$ and cathode: $0.5 \mathrm{M}$ $\mathrm{H}_{2} \mathrm{SO}_{4}$ ) at room temperature. For all experiments the fuel stream is $2 \mathrm{M}$ formic acid, and the oxidant stream is $0.1 \mathrm{M}$ perborate in the respective media. Stream flow rates: $0.3 \mathrm{~mL} \mathrm{~min}^{-1}$.

Overall:

$\mathrm{HCOO}^{-}+3 \mathrm{H}_{2} \mathrm{O}_{2}+6 \mathrm{H}^{+}+3 \mathrm{OH}^{-}+4 \mathrm{e}^{-} \longrightarrow \mathrm{CO}_{3}{ }^{2-}+8 \mathrm{H}_{2} \mathrm{O}$

$E^{\circ}=2.95 \mathrm{~V}$

In this acid-alkaline media 2 configuration, the combination of two galvanic reactions yields a desirable high theoretical OCP of $2.95 \mathrm{~V}$. Note that the inherent value of the electromotive force of the MLSPBFC is higher than that of the HFC $(1.23 \mathrm{~V})$ and the PEMFC or DMFC (1.21 V). However, because of the overpotentials resulting from the slow kinetics of peroxide reduction and formic acid oxidation, the open circuit potential is reduced to a measured value of $1.81 \mathrm{~V}$ (Figure 3). In the alkaline anode/acidic cathode acid-alkaline media configuration, both $\mathrm{OH}^{-}$and $\mathrm{H}^{+}$are consumed at the anode and cathode, respectively, at a rate of two for each molecule of formic acid.

Operating in this acid-alkaline media configuration, with an alkaline anode and an acidic cathode, resulted in a higher overall cell potential than those obtained for the all-acidic and all-alkaline MLSPBFC experiments. Figure 4 shows the power density curves of the MLSPBFC experiments performed in different media combinations at the anode and cathode.

In MLSPBFC, the all-acidic and all-alkaline experiments have maximum power densities of 2.81 and $6.0 \mathrm{~mW} \mathrm{~cm}^{-2}$, respectively, both at a cell potential of about $1.0 \mathrm{~V}$, whereas the acid-alkaline media experiment results in a power density maximum of $28.2 \mathrm{~mW} \mathrm{~cm}^{-2}$ at a cell potential of about $1.0 \mathrm{~V}$. 
TABLE 3: Effect of medium on the performance of the MLSPBFC.

\begin{tabular}{lccc}
\hline & All-alkaline & All-acidic & Acid-alkaline media 2 \\
\hline Open-circuit voltage $(\mathrm{V})$ & 1.16 & 0.93 & 1.81 \\
Short-circuit current density $\left(\mathrm{mA} \mathrm{cm}^{-2}\right)$ & 18.0 & 12.0 & 62.46 \\
Peak power density $\left(\mathrm{mW} \mathrm{cm}^{-2}\right)$ & 6.0 & 2.81 & 28.2 \\
Cell voltage at peak power density $(\mathrm{V})$ & 0.50 & 0.38 & 0.71 \\
Current density at peak power density $\left(\mathrm{mW} \mathrm{cm}^{-2}\right)$ & 12.0 & 7.39 & 39.85 \\
\hline
\end{tabular}

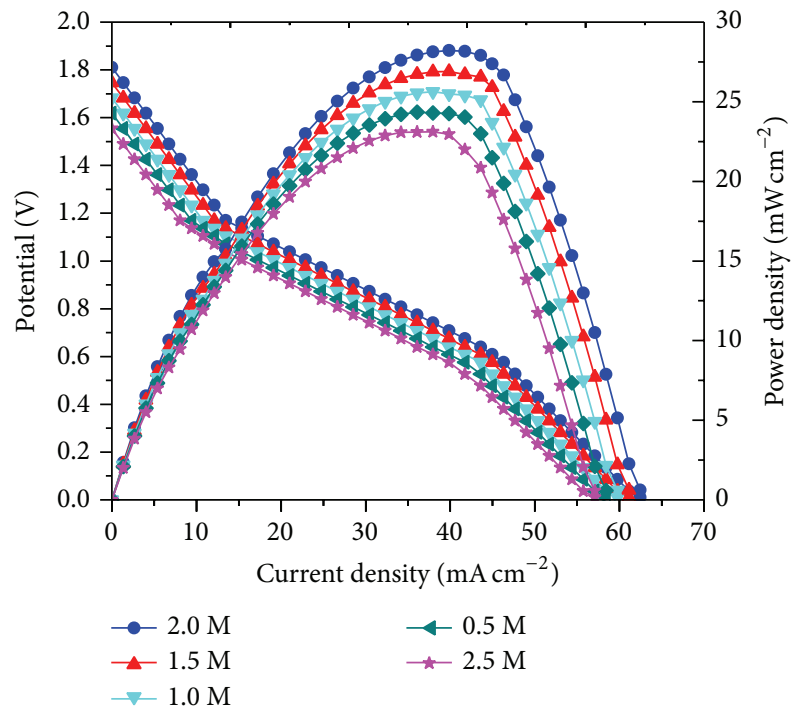

FIGURE 5: Effect of formic acid concentration on the current and power density of the MLSPBFC at room temperature. [Fuel]: $x \mathrm{M}$ formic acid $+0.5 \mathrm{M} \mathrm{NaOH}$. [Oxidant]: $0.1 \mathrm{M}$ perborate $+0.5 \mathrm{M}$ $\mathrm{H}_{2} \mathrm{SO}_{4}$. Stream flow rates: $0.3 \mathrm{~mL} \mathrm{~min}^{-1}$.

Within this condition, the acid-alkaline media fuel cell clearly outperforms both the all acidic and all-alkaline fuel cell (Table 3). The higher power densities in the acid-alkaline media MLSPBFC are a direct result of higher overall cell potentials due to the unprecedented ability to operate the cathode and anode at different $\mathrm{pH}$ in an MLSPBFC.

3.4. Influence of Fuel Composition. The effect of fuel on the performance of MLSPBFC has been observed by varying the formic acid concentration between $0.5 \mathrm{M}$ and $2.5 \mathrm{M}$ (Figure 5).

When fuel concentration is high, the limiting current density and the maximum power density are larger. As more reactants enter the cell, the mass transport to the electrodes increases. Accordingly, the current density and power density increases. However, the transport rate is limited by the depletion region [30]. Thus the current density did not increase significantly, while increasing the fuel concentrations beyond $2 \mathrm{M}$, which also suggests that the performance of the membraneless fuel cells is limited by slow anode/cathode kinetics or slow diffusion of reagents to the electrode surface due to the formation of a concentration boundary layer. From this we conclude that the concentration of formic acid as low as $0.5 \mathrm{M}$ did not result in a reduction of the cell performance,

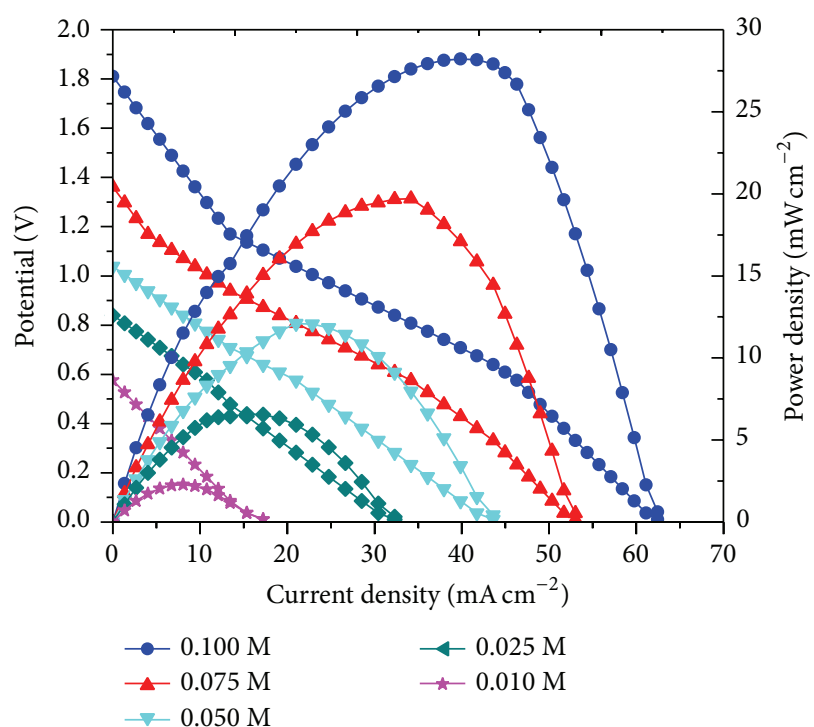

FIGURE 6: Effect of perborate concentration on the current and power density of the MLSPBFC at room temperature. [Fuel]: $2 \mathrm{M}$ formic acid $+0.5 \mathrm{M} \mathrm{NaOH}$. [Oxidant]: $x \mathrm{M}$ perborate $+0.5 \mathrm{M}$ $\mathrm{H}_{2} \mathrm{SO}_{4}$. Stream flow rates: $0.3 \mathrm{~mL} \mathrm{~min}^{-1}$.

which indicates that the cell is cathode limited [3]. In the present study, experimental results show that the fuel cell performance is maximum at $2 \mathrm{M}$ and further increase in the formic acid concentration has no significant effect on the fuel cell.

3.5. Influence of Oxidant Composition. The effects of perborate concentration on the cell performance were investigated at $0.01,0.025,0.05,0.075$, and $0.1 \mathrm{M}$. The power density increased in correlation to increased sodium perborate concentration in MLSPBFC and reached the maximum of $1.81 \mathrm{~V}$ at $0.1 \mathrm{M}$ sodium perborate. Peak power densities of 2.28, $6.58,12.10,19.70$, and $28.21 \mathrm{~mW} \mathrm{~cm}^{-2}$ were obtained at 0.01 , $0.025,0.05,0.075$, and $0.1 \mathrm{M}$, respectively (Figure 6). Further increase in the oxidant concentration shows no improvement in the cell performance. Therefore the value of $0.1 \mathrm{M}$ has been fixed for the perborate concentration in the oxidant solution.

The data of the exchange current density for anode and cathode also indicates that the activation losses are primarily due to the lower chemical activity at cathode. Accordingly we may conclude that the cell performance well be enhanced profoundly if the concentration of oxidant in cathodic stream 


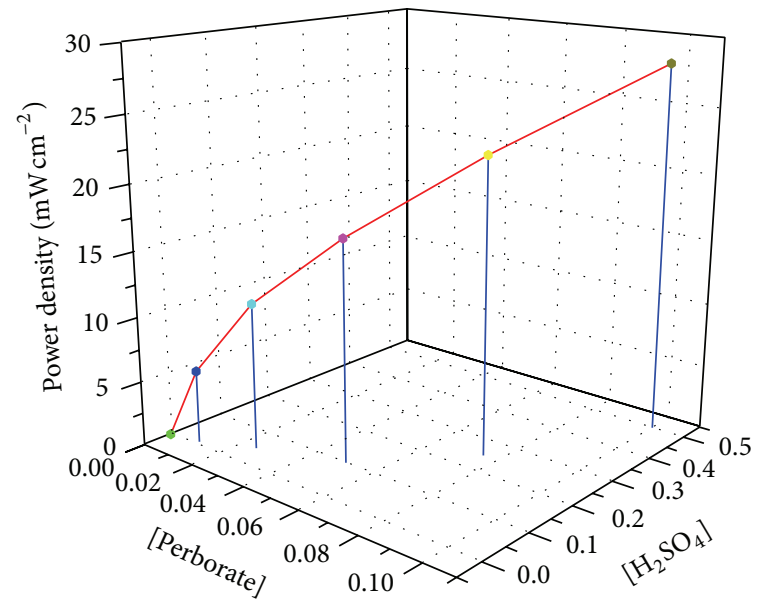

[Perborate]

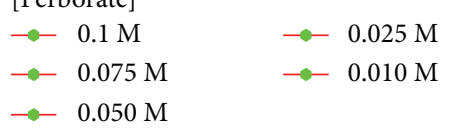

FIGURE 7: Effect of various combinations of perborate and sulphuric acid concentrations on the maximum power density $\left(28.2 \mathrm{~mW} \mathrm{~cm}^{-2}\right)$ of the MLSPBFC at room temperature. The fuel mixture for variation of oxidant is ([fuel]: $2 \mathrm{M}$ formic acid $+0.5 \mathrm{M}$ $\mathrm{NaOH}$, [oxidant]: $x \mathrm{M}$ perborate $\left.+0.5 \mathrm{M} \mathrm{H}_{2} \mathrm{SO}_{4}\right)$ and the fuel mixture for variation of sulphuric acid is ([fuel]: $2 \mathrm{M}$ formic acid + $0.5 \mathrm{M} \mathrm{NaOH}$, [oxidant]: $0.1 \mathrm{M}$ perborate $\left.+x \mathrm{M} \mathrm{H}_{2} \mathrm{SO}_{4}\right)$. Stream flow

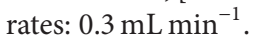

can be increased to raise concentration flux or the exchange current density at the cathode can be made as high as possible.

Likewise, the effect of $\mathrm{H}_{2} \mathrm{SO}_{4}$ compositions on the oxidant solution has also been analysed. The $\mathrm{H}_{2} \mathrm{SO}_{4}$ concentration was varied between $0.01 \mathrm{M}$ and $0.5 \mathrm{M}$. The maximum power density $\left(28.2 \mathrm{~mW} \mathrm{~cm}^{-2}\right.$ ) was obtained at $0.5 \mathrm{M} \mathrm{H}_{2} \mathrm{SO}_{4}$ (Figure 7). Further increase in the $\mathrm{H}_{2} \mathrm{SO}_{4}$ concentration shows no improvement in the cell performance. Therefore the value of $0.5 \mathrm{M}$ has been fixed for the $\mathrm{H}_{2} \mathrm{SO}_{4}$ concentration in the oxidant solution.

3.6. Influence of Distance Effect on the Performance of $M L S P B F C$. In order to find the potential benefit from a reduced diffusion length of reacting species moving between the anode and cathode, the fuel cell test was conducted for different distances between 1 and $100 \mathrm{~mm}$. When the distance between the anode and cathode decreased, the maximum power density increased as shown in Figure 8. Considering the role of a charge carrier, a shorter diffusion length is believed to give a faster electrochemical reaction because the diffusion time of reacting species would be shorter. Therefore, more reactions can take place at a given time, which increases the total number of charges involving the electrochemical reactions at the anode and cathode. This finding provides a good evidence of the presence of a charge carrier moving between the anode and cathode in the fuel mixture to complete redox reactions of the fuel cell [31].

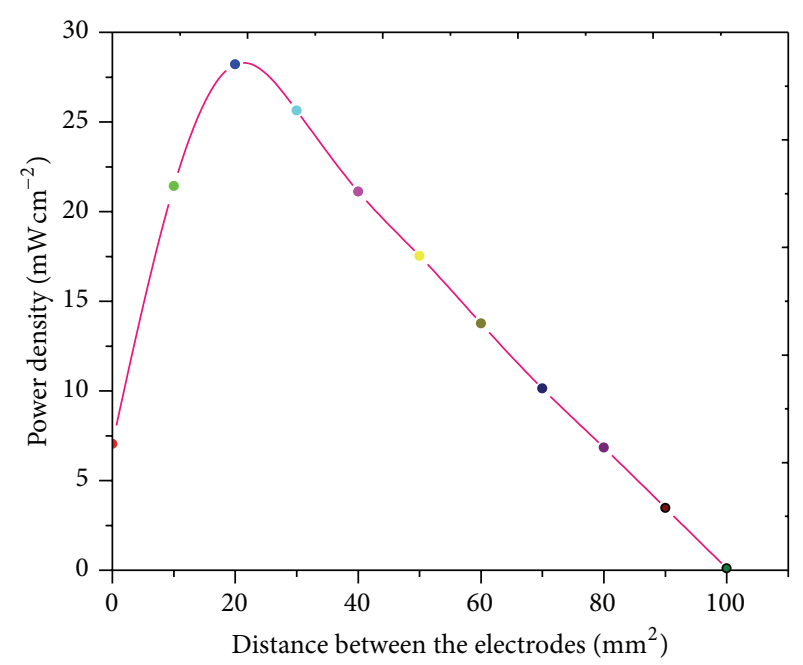

FIGURE 8: Effect of distance between anode and cathode on the maximum power density of the MLSPBFC at room temperature. [Fuel]: $2 \mathrm{M}$ formic acid $+0.5 \mathrm{M} \mathrm{NaOH}$. [Oxidant]: $0.1 \mathrm{M}$ perborate $+0.5 \mathrm{M} \mathrm{H}_{2} \mathrm{SO}_{4}$. Stream flow rates: $0.3 \mathrm{~mL} \mathrm{~min}^{-1}$.

3.7. Influence of Fuel Mixture Flow Rate. Since maximum power density is dependent on the transport time of reacting species it can be controlled by its flow rates. In this experiment, flow rates of $0.1,0.2,0.3,0.4,0.5,0.6,0.7,0.8,0.9$, and $1.0 \mathrm{~mL} \mathrm{~min}^{-1}$ were tested. The cell potential and current were measured with different external loads as a function of the flow velocity of fuel mixture. Using the flow rate applied and the cross-sectional area of the channel, a flow velocity can be calculated. In this work, the maximum power density is obtained at about $0.3 \mathrm{~mL} \mathrm{~min}^{-1}$; after that the maximum power density decreases with increase in flow rate as shown in Figure 9. It is believed that more electrochemical reactions would take place at a given time and a greater output current could develop in the end.

3.8. Stability Test. Durability of the MLSPBFC was examined under continuous test considering its practical applications. Short-term stability of MLSPBFC under acid-alkaline media configurations was tested by monitoring the cell voltage change during the galvanostatic discharge of $62 \mathrm{~mA} \mathrm{~cm}^{-2}$ of the MLSPBFC in a period of about $100 \mathrm{~h}$ (Figure 10). The MLSPBFC maintained a relatively stable performance with a little decay of cell voltage over the test period. The fluctuation in the cell voltage was due to addition of the new fuel solution, restarting the experiments, or small variation in cell temperature. The possible reasons for the gradual decline in cell performance with time may be due to the formation of $\mathrm{Na}_{2} \mathrm{CO}_{3}$. The result of the durability test showed that the MLSPBFC in our research has good stability at room temperature which is able to satisfy the necessary conditions as portable power sources.

\section{Conclusions}

A microscale membraneless sodium perborate fuel cell (MLSPBFC) was fabricated on PDMS and its performance 


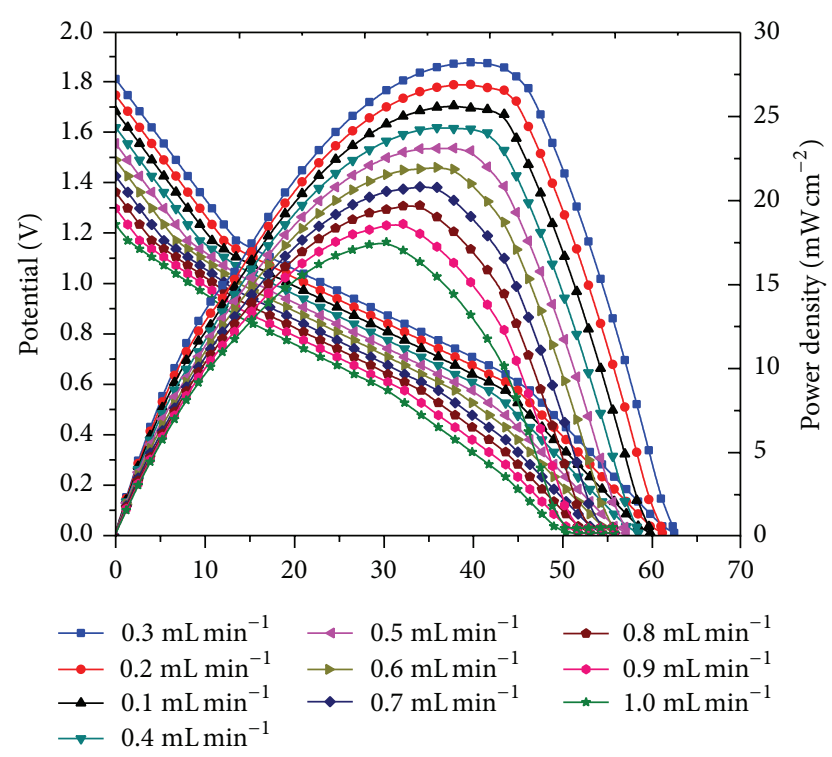

FIGURE 9: Effect of flow rate of fuel mixture on the current and power density of the MLSPBFC at room temperature. [Fuel]: $2 \mathrm{M}$ formic acid + 0.5 M NaOH. [Oxidant]: $0.1 \mathrm{M}$ perborate $+0.5 \mathrm{M} \mathrm{H}_{2} \mathrm{SO}_{4}$.

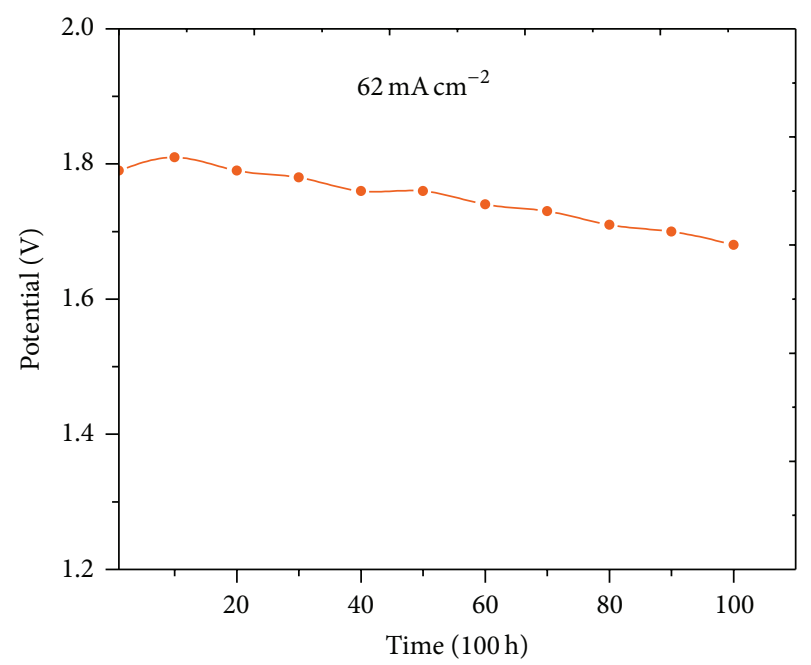

FIGURE 10: Performance stability of the MLSPBFC operating at current density of $62 \mathrm{~mA} \mathrm{~cm}^{-2}$ at room temperature. [Fuel]: $2 \mathrm{M}$ formic acid $+0.5 \mathrm{M} \mathrm{NaOH}$. [Oxidant]: $0.1 \mathrm{M}$ perborate $+0.5 \mathrm{M}$ $\mathrm{H}_{2} \mathrm{SO}_{4}$. Stream flow rates: $0.3 \mathrm{~mL} \mathrm{~min}^{-1}$.

was evaluated under different operating conditions. Standard microfabrication techniques were used to develop the device. In this membraneless fuel cell, formic acid is used as a fuel at the anode and sodium perborate is used as an oxidant at the cathode for the first time under "acid-alkaline media." The experiments described in this study show that membraneless sodium perborate fuel cells are media flexible; they can be operated in all-acidic, all-alkaline, or even acid-alkaline media configurations.

In this work, we observed that the alkaline anode/acidic cathode acid-alkaline media configuration leads to a very high measured OCP of $1.81 \mathrm{~V}$, while other combinations will result in very low OCPs as a result of the $\mathrm{pH}$ dependence of standard electrode potentials. The MLSPBFC operated in the alkaline anode/acidic cathode acid-alkaline media configuration; the measured OCP of $1.81 \mathrm{~V}$ is in good agreement with the theoretical OCP of $2.95 \mathrm{~V}$.

At room temperature, the laminar flow-based microfluidic fuel cell produced a maximum power density of $28.2 \mathrm{~mW} \mathrm{~cm}^{-2}$ under alkaline anode/acidic cathode acidalkaline media configurations. We concluded that acidalkaline media MLSPBFC seems to outperform the allacidic and all-alkaline MLSPBFC. The effects of flow rates of the fuel and oxidant, variation of concentrations of formic acid, perborate, and electrolytes were evaluated under acidalkaline media configurations. The performance was characterized by $V$ - $I$ curves and anode polarization plots.

The results demonstrated that the performance of the developed membraneless fuel cell enhanced profoundly if the concentration of oxidant in cathodic stream is 10 times larger, and the current density is also increased approximately ten times.

Thus, the present experimental findings have confirmed that this membraneless micro fuel cell is cathode limited and suggest that it is a crucial factor in improving cell performance to increase the concentration of oxidant in the cathodic stream. The flexibility of membraneless fuel cells to function with different media allowed the successful operation of mixed alkaline and acidic fuel cells. The membraneless micro fuel cell system investigated in this study seems to be a good candidate for feasible application because its performance is comparable to an air-breathing DMFC.

In addition, the development of metal catalysts to accelerate the efficiency of MLSPBFC is in progress. Some further experimental works towards the microchannel design and the flow rate of MLSPBFC with various fuels will be beneficial to verify the present predictions and fulfill the practical utilization in portable power sources.

The MLSPBFC have the advantages of their miniature sizes, simplicity of fabrication, use of aqueous fuel, and good cost efficiency. Furthermore, perborate is cheap, nontoxic, stable, easily handled, environment-friendly, and large-scale industrial chemical and is a convenient source of hydrogen peroxide. We expect that the MLSPBFC may be a promising candidate for practical fuel cells to establish a clean and sustainable energy future.

\section{Conflict of Interests}

The authors declare that they have no conflict of interests regarding the publication of this paper.

\section{Acknowledgment}

The financial support for this research from University Grants Commission (UGC), New Delhi, India, through a Major Research Project 42-325/2013 (SR) is gratefully acknowledged. 


\section{References}

[1] L. Carrette, K. A. Friedrich, and U. Stimming, "Fuel cells: principles, types, fuels, and applications," ChemPhysChem, vol. 1, no. 4, pp. 163-193, 2000.

[2] M. Eikerling, A. A. Kornyshev, A. M. Kuznetsov, J. Ulstrup, and S. Walbran, "Mechanisms of proton conductance in polymer electrolyte membranes," Journal of Physical Chemistry B, vol. 105, no. 17, pp. 3646-3662, 2002.

[3] E. R. Choban, L. J. Markoski, A. Wieckowski, and P. J. A. Kenis, "Microfluidic fuel cell based on laminar flow," Journal of Power Sources, vol. 128, no. 1, pp. 54-60, 2004.

[4] R. S. Jayashree, L. Gancs, E. R. Choban et al., "Air-breathing laminar low-based microfluidic fuel cell," Journal of the American Chemical Society, vol. 127, no. 48, pp. 16758-16759, 2005.

[5] J. L. Cohen, D. A. Westly, A. Pechenik, and H. D. Abruña, "Fabrication and preliminary testing of a planar membraneless microchannel fuel cell," Journal of Power Sources, vol. 139, no. 1-2, pp. 96-105, 2005.

[6] A. Bazylak, D. Sinton, and N. Djilali, "Improved fuel utilization in microfluidic fuel cells: a computational study," Journal of Power Sources, vol. 143, no. 1-2, pp. 57-66, 2005.

[7] M. Weber, J.-T. Wang, S. Wasmus, and R. F. Savinell, "Formic acid oxidation in a polymer electrolyte fuel cell: a real-time mass-spectrometry study," Journal of the Electrochemical Society, vol. 143, no. 7, pp. L158-L160, 1996.

[8] C. Rice, S. Ha, R. I. Masel, P. Waszczuk, A. Wieckowski, and T. Barnard, "Direct formic acid fuel cells," Journal of Power Sources, vol. 111, no. 1, pp. 83-89, 2002.

[9] G.-Q. Lu, A. Crown, and A. Wieckowski, "Formic acid decomposition on polycrystalline platinum and palladized platinum electrodes," Journal of Physical Chemistry B, vol. 103, no. 44, pp. 9700-9711, 1999.

[10] F. A. Cotton and G. Wilkinson, Advanced Inorganic Chemistry, Wiley Interscience, New York, NY, USA, 1988.

[11] C. Karunakaran and B. Muthukumaran, "Molybdenum(VI) catalysis of perborate or hydrogen peroxide oxidation of iodide ion," Transition Metal Chemistry, vol. 20, no. 5, pp. 460-462, 1995.

[12] M. Gowdhamamoorthi, A. Arun, S. Kiruthika, and B. Muthukumaran, "Enhanced performance of membraneless fuel cells," International Journal of ChemTech Research, vol. 5, no. 3, pp. 1143-1151, 2013.

[13] M. Gowdhamamoorthi, A. Arun, S. Kiruthika, and B. Muthukumaran, "Enhanced performance of membraneless sodium percarbonate fuel cells," Journal of Materials, vol. 2013, Article ID 548026, 7 pages, 2013.

[14] A. Arun, M. Gowdhamamoorthi, S. Kiruthika, and B. Muthukumaran, "Electrocatalyzed oxidation of methanol on carbon supported platinum electrode in membraneless sodium percarbonate fuel cells (MLSPCFC)," International Journal of ChemTech Research, vol. 5, no. 3, pp. 1152-1161, 2013.

[15] J. Yeom, G. Z. Mozsgai, A. Asthana et al., "A silicon microfabricated direct formic acid fuel cell," in Proceedings of the 1st International Conference on Fuel Cell Science, Engineering and Technology, pp. 267-272, April 2003.

[16] G. Q. Lu, C. Y. Wang, T. J. Yen, and X. Zhang, "Development and characterization of a silicon-based micro direct methanol fuel cell," Electrochimica Acta, vol. 49, no. 5, pp. 821-828, 2004.

[17] S. C. Kelley, G. A. Deluga, and W. H. Smyrl, "Miniature methanol/air polymer electrolyte fuel cell," Electrochemical and Solid-State Letters, vol. 3, no. 9, pp. 407-409, 2000.
[18] T. Yen, N. Fang, X. Zhanga, G. Q. Lu, and C. Y. Wang, "A micro methanol fuel cell operating at near room temperature," Applied Physics Letters, vol. 83, p. 4056, 2003.

[19] S. Motokawa, M. Mohamedi, T. Momma, S. Shoji, and T. Osaka, "MEMS-based design and fabrication of a new concept micro direct methanol fuel cell ( $\mu$-DMFC)," Electrochemistry Communications, vol. 6, no. 6, pp. 562-565, 2004.

[20] E. R. Choban, J. S. Spendelow, L. Gancs, A. Wieckowski, and P. J. A. Kenis, "Membraneless laminar flow-based micro fuel cells operating in alkaline, acidic, and acidic/alkaline media," Electrochimica Acta, vol. 50, no. 27, pp. 5390-5398, 2005.

[21] J. C. Shyu, C. L. Huang, T. S. Sheu, and H. Ay, "Experimental study of direct hydrogen peroxide microfluidic fuel cells," Micro \& Nano Letters, IET, vol. 7, pp. 740-743, 2012.

[22] Y. Ayato, T. Okada, and Y. Yamazaki, "Characterization of bipolar ion exchange membrane for polymer electrolyte fuel cells," Electrochemistry, vol. 71, no. 5, pp. 313-317, 2003.

[23] E. R. Choban, P. Waszczuk, L. J. Markoski, A. Wieckowski, and P. J. A. Kenis, Rochester, NY, USA, 2003.

[24] E. R. . Choban, L. J. Markoski, J. Stoltzfus, J. S. Moore, and P. J. A. Kenis, "Microfluidic fuel cells that lack a polymer electrolyte membrane," in Power Sources Proceedings, vol. 40, pp. 317-320, 2002.

[25] J. S. Spendelow, G. Q. Lu, P. J. A. Kenis, and A. Wieckowski, "Electrooxidation of adsorbed CO on $\mathrm{Pt}(111)$ and $\mathrm{Pt}(111) / \mathrm{Ru}$ in alkaline media and comparison with results from acidic media," Journal of Electroanalytical Chemistry, vol. 568, no. 1-2, pp. 215224, 2004.

[26] G. F. McLean, T. Niet, S. Prince-Richard, and N. Djilali, "An assessment of alkaline fuel cell technology," International Journal of Hydrogen Energy, vol. 27, no. 5, pp. 507-526, 2002.

[27] T. Iwasita, "Electrocatalysis of methanol oxidation," Electrochimica Acta, vol. 47, no. 22-23, pp. 3663-3674, 2002.

[28] D. R. Lide, CRC Handbook of Chemistry and Physics, CRC Press LCC, MARC Records Transmitter System, 85th edition, 2005.

[29] E. H. Yu and K. Scott, "Development of direct methanol alkaline fuel cells using anion exchange membranes," Journal of Power Sources, vol. 137, no. 2, pp. 248-256, 2004.

[30] H. B. Park, K. H. Lee, and H. J. Sung, "Performance of H-shaped membraneless micro fuel cells," Journal of Power Sources, vol. 226, pp. 266-271, 2013.

[31] W. Sung and J.-W. Choi, "A membraneless microscale fuel cell using non-noble catalysts in alkaline solution," Journal of Power Sources, vol. 172, no. 1, pp. 198-208, 2007. 

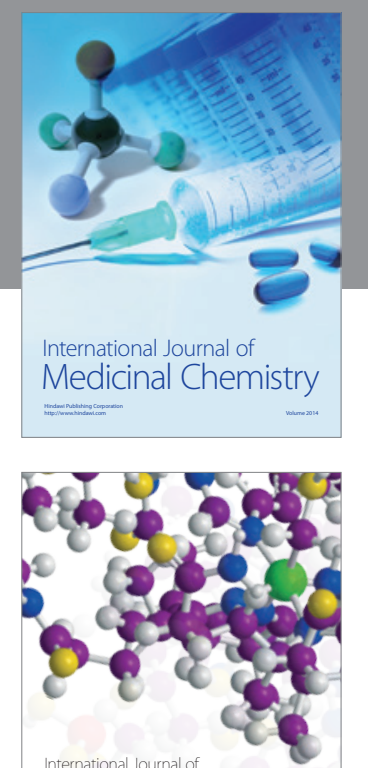

\section{Carbohydrate} Chemistry

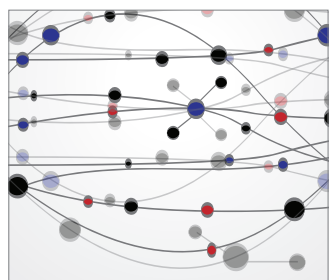

The Scientific World Journal
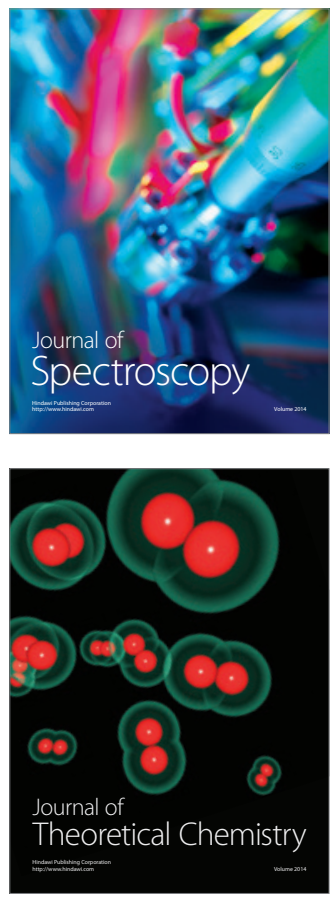
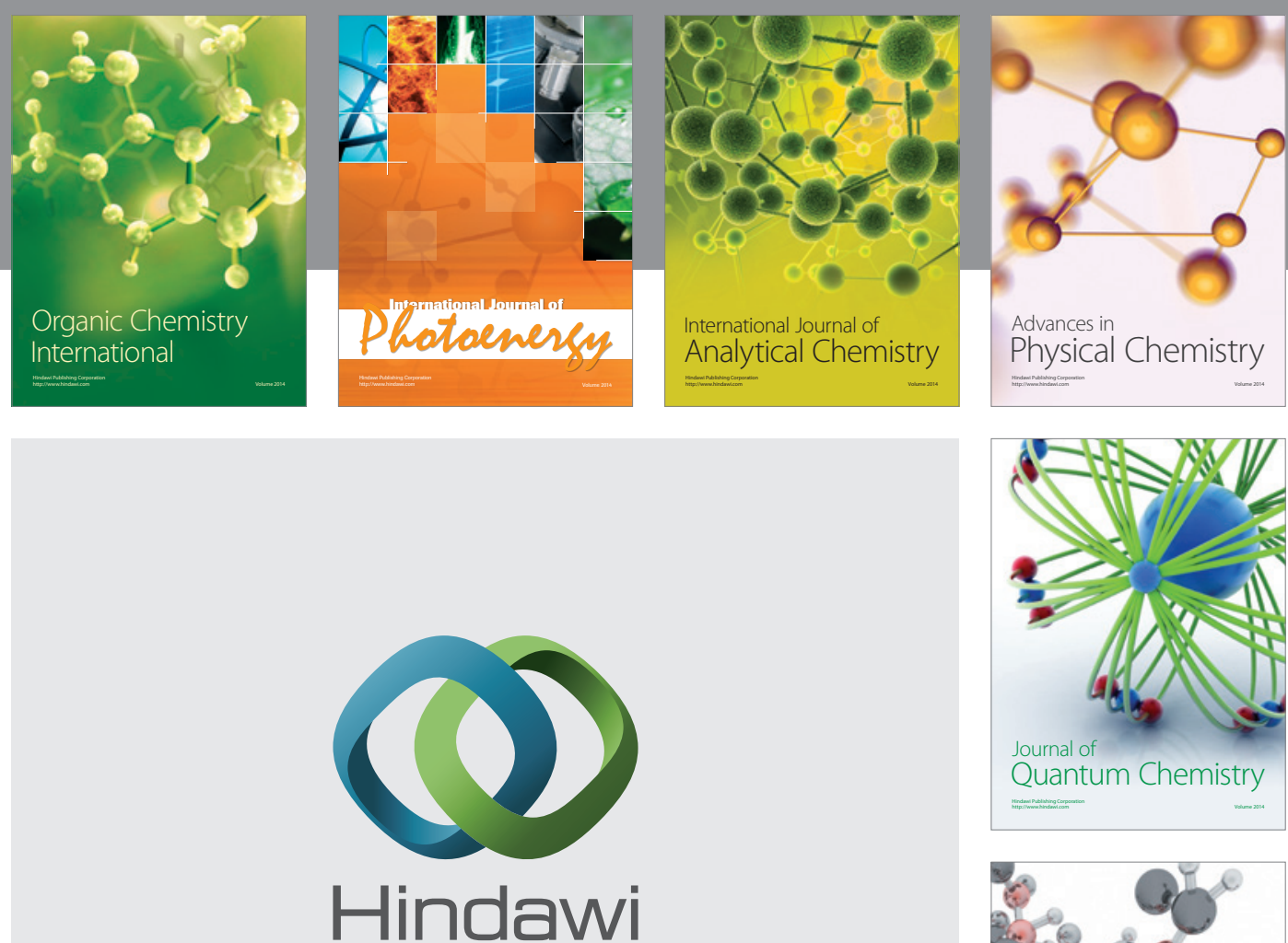

Submit your manuscripts at

http://www.hindawi.com

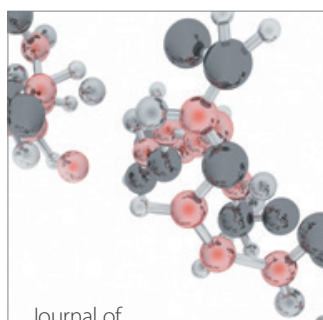

Analytical Methods

in Chemistry

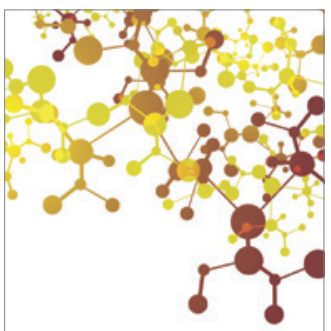

Journal of

Applied Chemistry

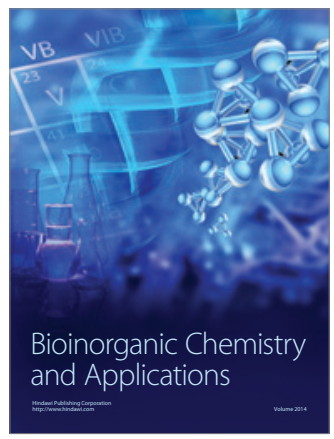

Inorganic Chemistry
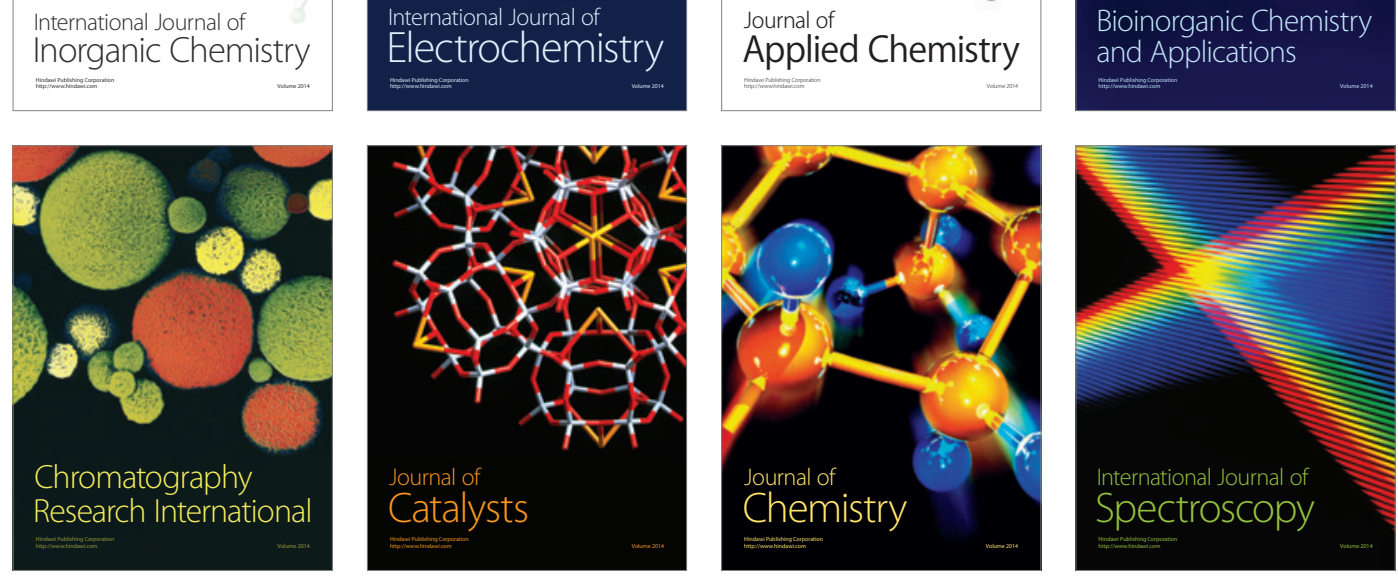